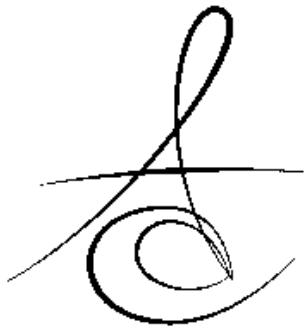

\title{
COMPARISON OF THE POSTOPERATIVE PAIN AND DISCOMFORT AFTER DIODE LASER AND CONVENTIONAL FRENECTOMY
}

\section{KONVANSİYONEL VE DİYOT LAZER YÖNTEMLERİ İLE YAPILAN FRENEKTOMİ İŞLEMİ SONRASI AĞRI VE HASTA KONFORUNUN KARŞILAŞTIRILMASI}

\author{
Yrd. Doç. Dr. Hatice BALCI YÜCE* \\ Dt. Özkan KARATAŞ*
}

\author{
Dt. Feyza TULU* \\ Dt. Fatma UÇAN YARKAÇ*
}

Makale Kodu/Article code: 2893

Makale Gönderilme tarihi: 21.06.2016

Kabul Tarihi: 30.11 .2016

\section{ABSTRACT}

Aim: Frenulum is a sagittal fibrous fold of oral mucosa with a periosteal insertion that extends from the lip or cheek to the alveolar or gingival mucosa. Sometimes frenulums have high attachments and wide soft tissue folds and these high frenulums may cause functional and aesthetic problems. The aim of this study is evaluate the pain and discomfort in patients treated with conventional or diode laser frenectomy through VAS scale.

Material-method: In this study, in totally 74 patients frenectomy procedure was indicated. 39 patients had frenectomy performed with conventional surgery (Group C) and 35 patients had frenectomy performed with laser surgery (Group $L$ ). None of the patients had systemic disease or any prescribed drug use. A VAS scale was prepared in order to evaluate pain and discomfort in speaking and chewing. All patients were informed about how to fill the form in detail and a form was given to each patient. All patients were recalled at $10^{\text {th }}$ day and VAS scale forms were recollected.

Results: There were no significant differences in demographic data of the groups $(p>0.05)$. Pain was found to be significantly higher in conventional group $(p<0.05)$. Likewise, discomfort in speaking and chewing was also significantly lower in laser surgery group than conventional surgery $(p<0.05)$.

Conclusion: Diode laser frenectomy procedure caused lower pain and discomfort in speaking and chewing, and within the limitations of this study, based on these results it can be concluded that diode laser surgery had beneficial results in frenectomy procedure.

Key words: Diode Laser; Frenectomy; Pain, Visual Analog Scale (VAS).

\section{ÖZ}

Amaç: Frenilum dudak ve yanaklardan ağız mukozası veya yapışık dişetine uzanan, periosta tutunan kas ve bağ dokusu liflerinden oluşan fizyolojik-anatomik bir bağlantıdır. Bazı hastalarda frenilum yüksek seviyede ataçman ve geniş mukoza katlantıları yaparak fonksiyonel ve/veya estetik problemlere neden olabilir. Bu gibi durumlarda cerrahi olarak alınması gereklidir. Frenektomi konvansiyonel olarak uygulandığında sütür gerektirir ve sonrasında kanama, şş̧lik ve ağrı olabilir. Lazer uygulaması, kanama olmaması, sütür gerektirmemesi ve hasta konforu açısından tercih edilmektedir. Bu çalışmanın amacı konvansiyonel ve diyot lazer cerrahisi ile yapılan frenektomi işlemi sonrasında VAS skalası aracılığıla ağrı, konuşma ve çiğneme güçlüğünün değerlendirilmesidir.

Gereç ve Yöntem: Frenektomi endikasyonu konulmuş toplam 74 hastada 39 hastaya konvansiyonel cerrahi (K grubu) uygulanmış, 35 hastaya ise diyot lazer cerrahisi (L grubu) ile frenektomi uygulanmıştır. Dahil edilen hastalar sistemik hastalığı olmayan, düzenli ilaç kullanmayan hastalardı. Ağrı, çiğneme ve konuşma fonksiyonlarının değerlendirilebilmesi için hazırlanan VAS skalası formu hastalara verilerek nasıl doldurmaları gerektiği detaylı bir biçimde anlatılmıştır. Hastalar işlem sonrası 10. günde kontrole çağırılmıştır.

Bulgular: Her iki grup arasında yaş ve cinsiyet dağılı- mı açısından fark bulunmadı ( $p>0.05$ ). Ağrı konvansi- yonel grupta lazer gurubuna oranla anlamlı düzeyde yüksek bulundu $(p<0.05)$. Aynı şekilde lazer grubunda konvansiyonel gruba oranla daha az konuşma ve çiğneme güçlüğü yaşandı $(p<0.05)$.

Sonuç: Diyot lazer ile frenektomi cerrahisi konvansiyonel cerrahiye oranla daha az ağrı, konuşma ve çiğneme güçlüğüne neden olmuştur ve bu çalışmanın sınırları dahilinde, bu sonuçlara dayanarak diyot lazerin frenektomi cerrahisinde faydalı sonuçlar verdiği söylenebilir.

Anahtar Kelimeler: Ağrı, Diyot lazer; Frenektomi, Visual Analog Skala(VAS).

* Gaziosmanpasa University Faculty of Dentistry Department of Periodontology 
Atatürk Üniv. Diş Hek. Fak. Derg.

J Dent Fac Atatürk Uni

Cilt:27, Sayı:2, Yıl: 2017, Sayfa, 57-62
BALCI YÜCE, TÜLÜ,

KARATAŞ, UÇAN YARKAÇ

\section{INTRODUCTION}

A frenum is an anatomical structure which forms a fibrous mucous membrane fold and often involves connective tissue and/or muscle fibers. It connects to the gingival, lip and/or cheek mucosa and sometimes periosteum. If there is a hypertrophy, frenum attaches to a more coronal location and generates a higher attachment. ${ }^{1}$ Encroachment of frenum to the attached gingiva might compromise oral hygiene, cause plaque accumulation leading to aesthetic and functional problems such as gingival recession, caries, dentin hypersensitivity and further gingival inflammation and periodontal bone loss. In such cases, surgical excision of frenum should be planned for prophylaxis. ${ }^{1,2}$

Frenectomy can be performed via conventional surgical excision, laser or electrocauter surgeries. ${ }^{1-4}$ Conventional technique involves surgical excision of frenum with a scalpel. This technique also requires sutures and post-operative bleeding, pain or swelling might occur in operation area. These disadvantages of conventional technique can be remedied by laser frenectomy. There are no sutures required in laser operations and no bleeding occurs during surgery or in post-operative period. Laser surgery was also reported to cause less swelling and post-operative pain. ${ }^{5-8}$ These features make laser more desirable than conventional surgeries.

Lasers are commonly used in both dentistry and medical applications. In dentistry, it is generally preferred for resective gingival/mucosal surgeries such as frenectomy, gingivectomy, gingivoplasty and epulis fissuratum ${ }^{9-13}$, and oral lesions such as leukoplakia, oral lichen planus and mucous membrane pemphigoid. 13-15 Medical applications of laser surgery involve treatment of vascular lesions such as hemangioma and telangiectasia. ${ }^{16}$

As one of the most preferred lasers, diode laser is an electrically pumped semiconductor laser which converts electrical energy into light energy ${ }^{17-19}$. Diode wavelengths range from 810 to $1,100 \mathrm{~nm}$, and are poorly absorbed by hard tissues ${ }^{12}$ but can be absorbed by soft tissues, melanin and also partly oxyhemoglobin. ${ }^{20}$ Diode laser was reported to be effective in preventing pain and bleeding providing less discomfort after surgeries. ${ }^{18,17}$
In order to evaluate the effects of lasers on pain, a reliable and sensitive measure should be used. In this regard, visual analogue scale (VAS) was reported to be a useful tool in terms of evaluating subjective characteristics or attitudes which cannot be directly measured, in present case, post-operative pain. ${ }^{4,5,21-23}$ It also provides a psychometric response scale which could be used in questionnaires and modified according to the relevant procedure. ${ }^{4}$

Based on the suggested favorable effects of diode laser in the literature, we hypothesized that pain and discomfort caused by frenectomy procedure would be lesser than conventional method. Thus, the aim of this study was evaluate the pain and discomfort in patients treated with conventional or diode laser frenectomy through VAS scale.

\section{MATERIAL and METHODS}

This study was conducted in Gaziosmanpasa University faculty of Dentistry Department of Periodontology with the approval of Clinical Studies Ethical Committee of Gaziosmanpasa University Faculty of Medicine, Tokat, Turkey. Frenectomy procedure indicated volunteer individuals who signed an informed consent were involved in this study. None of the patients had systemic diseases or conditions (such as pregnancy or lactation), were under antibiotic, anti-inflammatory or analgesic therapy and had severe oral disease or condition (such as pericoronitis, root canal treatment indication, aphthous stomatitis, tooth extraction indication, lichen planus or the other white-red lesions of oral mucosa) causing pain and/or disturbance in speaking or chewing.

Totally 74 patients were enrolled in this study. Study groups were as follows:

1. Conventional surgery group (group $C, n=39$, 7 male, 32 female, mean age $30.26 \pm 15.05$ )

2. Laser surgery group (group $L, n=35,7$ male, 28 female, mean age $31.85 \pm 16.10$ ) the laser adjustments were $940 \mathrm{~nm}, 1.2 \mathrm{~W}$.

For the conventional surgery, after application of local infiltration anesthesia of lidocaine (2\%) combined with epinephrine $1: 100,000$, the frenum was grasped with a straight haemostat inserted into the depth of the vestibule; the tissue adjacent to the upper and lower surfaces of the haemostat was incised with a no.15 scalpel. After the triangular

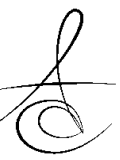


Atatürk Üniv. Diş Hek. Fak. Derg.

J Dent Fac Atatürk Uni

Cilt:27, Sayı:2, Yıl: 2017, Sayfa, 57-62

resected portion of the frenum was removed with the haemostat, muscle dilatations were performed using curved forceps on the submucosa of the lateral walls of the cavity formed after the excision of the frenum. At the end of the operation, the wound was closed with absorbable sutures (4-0 vicryl, Ethicon, Ohio, USA).

For the laser frenectomy, a diode laser device ( $\lambda=940 \mathrm{~nm}, \mathrm{~W}: 1.2$, BioLase, California, USA) was used to perform the procedure. The procedure was performed under local infiltration anesthesia with lidocaine (2\%) associated with epinephrine 1:100,000. The frenum was held by a haemostat inserted into the depth of the vestibule while laser energy was applied to the upper and lower parts of the frenum adjacent to the haemostat via a fibre tip. The laser was carefully applied to the tissue and care was taken to avoid local necrosis of the periosteum or any bone structure. No sutures were necessary after procedure. $500 \mathrm{mg}$ paracetamol was prescribed for all patients (two times a day for 5 days, taken orally, based on weight) to control the postoperative pain, if necessary.

Post-operative care was recommended and the oral and written instructions were given. VAS scale to evaluate pain was adapted to discomfort in speaking and chewing. Conventional VAS scale is consisted of a horizontal line with a range of numbers from ' 0 ' to ' 10 ' of which ' 0 ' means 'no pain', 5 means 'moderate pain' and ' 10 ' means unbearable pain. In this study, the scale was modified to evaluate the pain and discomfort at the operation day and after first, third, seventh and ninth day (Figure 1). Patients were given appointments for a control session 10 days after operation. The VAS forms were collected from the patients at the control session.

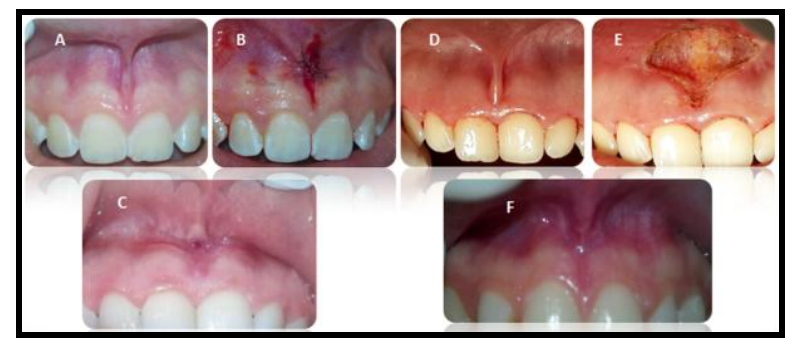

Figure 1. Representative pre-operative, operative and postoperative photographs at $10^{\text {th }}$ day of the study groups. Images $A, B$ and $C$ show the conventional surgery group and images $D, E$ and $F$ show the laser surgery group.
BALCI YÜCE, TÜLÜ,

KARATAŞ, UÇAN YARKAC

\section{Statistical Analysis}

Data were expressed as mean and standard deviation (SD), scores and percentage as appropriate. Analysis of normality was performed and parametric tests were used based on the distribution of the data. Independent samples $t$ test and chi-square test were used. Power of performed test with alpha $=0,050$ was 0,800 and accordingly the power of this study was found $80 \%$. All statistical analysis were performed via SPSS programme (Vs 20.0) and $\mathrm{p}<0.05$ was considered statistically significant.

\section{RESULTS}

The results of the present study were summanzed in Table 1. No significant difference regarding the age and gender distribution was observed between the study groups $(p>0.05)$. Mean VAS scores of pain were $2.91 \pm 2.07$ in the $C$ group and $1.81 \pm 1.78$ in the $L$ group and the difference was found statistically significant $(p<0.05)$. In terms of discomfort in speaking, there was a statistically significant difference between groups and mean VAS scores of speaking discomfort were $2.60 \pm 2.39$ in $C$ group and $1.37 \pm 1.92$ in $L$ group $(p<0.05)$. Lastly, evaluation of discomfort in chewing showed that the mean VAS score of the $L$ group was significantly lower than $C$ group $(1.72 \pm 2.08$ and $2.97 \pm 2.23$, relatively) $(p<0.05)$.

Table 1: Gender distribution, mean age and the VAS scores of pain, discomfort in speaking and chewing in the groups

\begin{tabular}{|l|c|c|l|}
\hline $\begin{array}{l}\text { Groups/ } \\
\text { Parameters }\end{array}$ & $\begin{array}{c}\text { Conventional } \\
\text { surgery } \\
\mathrm{n}=39\end{array}$ & $\begin{array}{c}\text { Laser surgery } \\
\mathrm{n}=35\end{array}$ & $\mathrm{p}$ values \\
\hline Age & $29.10 \pm 14.90$ & $30.90 \pm 16.70$ & $\mathrm{P}>0.05$ \\
\hline Gender & $\begin{array}{c}32 \text { female } \\
7 \text { male }\end{array}$ & $\begin{array}{c}28 \text { female } \\
7 \text { male }\end{array}$ & $\mathrm{P}>0.05$ \\
\hline Mean VAS scores of pain & $2.91 \pm 2.07$ & $1.81 \pm 1.78$ & $\mathrm{P}=0.01^{*}$ \\
\hline $\begin{array}{l}\text { Mean VAS scores of } \\
\text { discomfort in speaking }\end{array}$ & $2.60 \pm 2.39$ & $1.37 \pm 1.92$ & $\mathrm{P}=0.01^{*}$ \\
\hline $\begin{array}{l}\text { Mean VAS scores of } \\
\text { discomfort in chewing }\end{array}$ & $2.97 \pm 2.23$ & $1.72 \pm 2.08$ & $\mathrm{P}=0.01^{*}$ \\
\hline
\end{tabular}

$*_{p}<0.05$ statistically significant difference

\section{DISCUSSION}

In present study, we evaluated the postoperative comfort of two different surgical approaches in frenectomy procedure and found that laser surgery provided better outcomes regarding the pain and discomfort in speaking and chewing that conventional

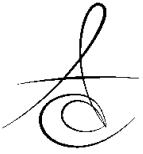


surgery. In present study, VAS was used to evaluate pain and with modification it was also used for discomfort in speaking and chewing.

Pain is a subjective perception and it is not possible to make an objective assessment. However, there are some different methods for evaluating the pain. ${ }^{21,22}$ VAS is one of the most commonly used methods to assess pain $4,5,23$ and it is short and easy to understand and it also provides an effective assessment for both patients and clinicians. ${ }^{23}$ Along with VAS, visual numeric scale (VNS) was also used to evaluate post-operative pain and fear after frenectomy surgeries. ${ }^{5,24}$ In present study, we assessed the pain and discomfort in speaking and chewing via a modified VAS scale.

In present study, we used diode laser for laser procedure. Compared to the other lasers, diode lasers are relatively small and they are often preferred due to the portability and low cost. ${ }^{19,25,26}$ Diode lasers are absorbed by melanin and hemoglobin with a deep penetration. ${ }^{27}$ Their use in dental practice mainly includes soft tissue excision, endodontic, periodontal and surgical disinfection, intra-pocket deepithelization, coagulation and also biostimulation. ${ }^{28-}$ ${ }^{31}$ In clinical applications, lasers can be used either as sole treatment tool or adjuvant to the other procedures and they provide clear advantages over conventional surgery such as hemostasis, wound disinfection and no suture requirement. ${ }^{19,} 30$ However they have certain disadvantages such as slow work, prolongation of operation time and heat, and in addition, when used in inappropriate conditions tissue carbonization also occur. ${ }^{19,} 30$

Despite those disadvantages, studies showed successful results of lasers in treatment of soft tissue lesions. ${ }^{13,} 20$ Diode laser was reported to be useful in excisional biopsy of oral mucosal lesions. ${ }^{32}$ Boj et al. reported that lasers increased the success of the procedures and improved the prognosis in crown lengthening, pericoronitis, frenectomy, pulpotomy and excision of pyogenic granuloma. 33, 34 Haytac and Ozcelik indicated that laser frenectomy procedure provided better patient perception and function and lesser postoperative pain. ${ }^{6}$ Regarding to frenectomy procedure, the decrease in pain, bleeding and scar formation provided by laser make laser more desirable than conventional surgery. ${ }^{5,10}$ Akpinar et al. demonstrated that Nd:YAG lasers decreased the post- operative pain and provided better comfort to the patients after frenectomy procedure. 4 However $\mathrm{Nd}$ :YAG lasers are relatively expensive and big devices, thus they may not be suitable for daily clinical practice. On the other hand, due to their ergonomic structure, small size and low cost, diode lasers can overcome these advantages and find itself more use of space.

Studies evaluating the post-operative pain after diode laser surgery revealed that patients treated with the diode laser had less postoperative pain and discomfort with remarkable satisfactory results and healing compared to patients treated with the conventional technique. ${ }^{35-38}$ Recently, Farista et al. demonstrated that diode laser decreased VAS scores significantly than conventional surgery in crown lengthening. ${ }^{36}$ In a study evaluating the effect of diode laser on depigmentation, El Shenawy et al. stated that diode laser can be used as a safe and effective treatment modality to provide optimal aesthetics with reduced discomfort. ${ }^{37}$ Furthermore, diode laser was found to decrease pain more than the other types of lasers. ${ }^{12}$ Kafas et al. stated that lingual frenectomy could be performed even without local anesthesia. ${ }^{10}$ It is also shown that orthodontic patients treated with the diode laser required less infiltration anesthesia and improved postoperative comfort and healing. ${ }^{39}$ We found that diode laser effectively decreased pain and these results are compatible with the literature. ${ }^{3,18,39-41}$ In addition to reduction in pain, we also revealed that diode laser provided a comfortable post-operative period in terms of speaking and chewing. These favorable aspects of diode laser can facilitate clinical practice and make dental surgeries more tolerable to the patients.

\section{CONCLUSIONS}

Diode laser has been proven to be an effective tool in dental practice in terms of hemostasis, wound healing, biostimulation and decreasing pain. Ergonomical features and low cost are also reason of choice. In present study, we evaluated the effect of diode laser on post-operative pain and discomfort and as a result, we found that diode laser successfully decreased pain and discomfort. We can conclude that diode laser provides a better patient perception and laser frenectomy can be used instead of conventional surgery. 


\section{REFERENCES}

1. Devishree, Gujjari SK, Shubhashini PV. Frenectomy: a review with the reports of surgical techniques. Journal Of Clinical And Diagnostic Research : JCDR 2012;6:1587-92.

2. Delli K, Livas C, Sculean A, Katsaros C, Bornstein $M M$. Facts and myths regarding the maxillary midline frenum and its treatment: a systematic review of the literature. Quintessence Int 2013;44:177-87.

3. Gargari M, Autili N, Petrone A, Prete V. Using the diode laser in the lower labial frenum removal. ORAL \& Implantology 2012;5:54-7.

4. Akpinar A, Toker H, Lektemur Alpan A, Calisir M. Postoperative Discomfort After Nd: YAG laser and conventional frenectomy: comparison of both genders. Australian Dental Journal 2015.

5. Haytac MC, Ozcelik O. Evaluation of patient perceptions after frenectomy operations: a comparison of carbon dioxide laser and scalpel techniques. J Periodontology 2006; 77: 1815-9.

6. Shetty K, Trajtenberg C, Patel C, Streckfus C. Maxillary frenectomy using a carbon dioxide laser in a pediatric patient: a case report. General Dentistry 2008;56:60-3.

7. Pie-Sanchez J, Espana-Tost AJ, ArnabatDominguez J, Gay-Escoda C. Comparative study of upper lip frenectomy with the $\mathrm{CO} 2$ laser versus the Er, Cr:YSGG laser. Medicina Oral, Patologia Oral Y Cirugia Bucal 2012;17:e228-32.

8. De Santis D, Gerosa R, Graziani PF, et al. Lingual frenectomy: a comparison between the conventional surgical and laser procedure. Minerva Stomatologica 2013.

9. Romanos G. Current concepts in the use of lasers in periodontal and implant dentistry. Journal of Indian Society of Periodontology 2015;19:490-494.

10. Kafas P, Stavrianos C, Jerjes W, et al. Upper-lip laser frenectomy without infiltrated anaesthesia in a paediatric patient: a case report. Cases J 2009; 2:7138.

11. Ishikawa I, Aoki A, Takasaki AA. Clinical application of erbium:YAG laser in periodontology. Journal of the International Academy of Periodontology 2008; 10:22-30.

12. Aras MH, Goregen M, Gungormus M, Akgul HM. Comparison of diode laser and Er:YAG lasers in the treatment of ankyloglossia. Photomedicine and
Laser Surgery 2010;28:173-7.

13. Goharkhay K, Moritz A, Wilder-Smith $P$, et al. Effects on oral soft tissue produced by a diode laser in vitro. Lasers İn Surgery And Medicine 1999;25:401-6.

14. Vivek V, Jayasree RS, Balan A, Sreelatha KT, Gupta AK. Three-year follow-up of oral leukoplakia after neodymium:yttrium aluminum garnet (Nd:YAG) laser surgery. Lasers in Medical Science 2008;23:375-9.

15. van der Hem $P S$, Egges $M$, van der Wal $J E$, Roodenburg JL. CO2 laser evaporation of oral lichen planus. International Journal Of Oral And Maxillofacial Surgery 2008;37:630-3.

16. Saetti R, Silvestrini M, Cutrone C, Narne S. Treatment of congenital subglottic hemangiomas: our experience compared with reports in the literature. Archives Of Otolaryngology--Head \& Neck Surgery 2008;134:848-51.

17. Azma E, Safavi N. Diode laser application in soft tissue oral surgery. Journal Of Lasers İn Medical Sciences 2013;4:206-11.

18. Stubinger S, Saldamli B, Jurgens P, Ghazal G, Zeilhofer HF. [Soft tissue surgery with the diode laser--theoretical and clinical aspects]. Schweizer Monatsschrift fur Zahnmedizin = Revue mensuelle suisse d'odonto-stomatologie $=$ Rivista mensile svizzera di odontologia e stomatologia / SSO 2006;116:812-20.

19. Andreana S. The use of diode lasers in periodontal therapy: literature review and suggested technique. Dentistry today 2005;24:130, 132-135.

20. Akbulut N, Kursun ES, Tumer MK, Kamburoglu K, Gulsen U. Is the $810-\mathrm{nm}$ diode laser the best choice in oral soft tissue therapy? European Journal Of Dentistry 2013;7:207-11.

21. Benhamou D. [Evaluation of postoperative pain]. Annales francaises d'anesthesie et de reanimation 1998; 17:555-72.

22. Williamson A, Hoggart B. Pain: a review of three commonly used pain rating scales. Journal of Clinical Nursing 2005;14:798-804.

23. Yucel A, Senocak M, Kocasoy Orhan E, Cimen A, Ertas M. Results of the Leeds assessment of neuropathic symptoms and signs pain scale in Turkey: a validation study. The journal of pain : official journal of the American Pain Society 2004;5:427-32.

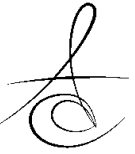


Atatürk Üniv. Diş Hek. Fak. Derg.

J Dent Fac Atatürk Uni

Cilt:27, Sayı:2, Yıl: 2017, Sayfa, 57-62
BALCI YÜCE, TÜLÜ,

KARATAŞ, UÇAN YARKAÇ
24. Medeiros Junior $R$, Gueiros LA, Silva IH, de Albuquerque Carvalho A, Leao JC. Labial frenectomy with Nd:YAG laser and conventional surgery: a comparative study. Lasers in Medical Science 2015;30:851-6.

25. Deppe $\mathrm{H}$, Horch $\mathrm{HH}$. Laser applications in oral surgery and implant dentistry. Lasers in medical Science 2007;22:217-21.

26. Coleton S. Lasers in surgical periodontics and oral medicine. Dental clinics of North America 2004;48:937-962, vii.

27. Leclere FM, Magalon G, Philandrianos C, Unglaub $F$, Servell $P$, Mordon S. Prospective ex-vivo study on thermal effects in human skin phototypes II, IV and VI: a comparison between the 808, 1064, 1210 and $1320-n m$ diode laser. Journal of cosmetic and laser therapy : official publication of the European Society for Laser Dermatology 2012;14:7-13.

28. Uysal D GC. Laser in dentıstry: a literature review J Dent Fac Atatürk Uni 2012; Supplementary:44-53.

29. Stabholz A, Zeltser R, Sela M, Peretz B, Moshonov J, Ziskind $D$. The use of lasers in dentistry: principles of operation and clinical applications. Compend Contin Educ Dent 2003;24:935-48;

30. Slot DE, Jorritsma KH, Cobb CM, Van der Weijden FA. The effect of the thermal diode laser (wavelength 808-980 $\mathrm{nm}$ ) in non-surgical periodontal therapy: a systematic review and meta-analysis. Journal Of Clinical Periodontology 2014; 41:681-92.

31. Saglam E SN, Emrem Doğan G. The treatment of ankyloglossia with frenectomy: case report. J Dent Fac Atatürk Uni 2015;25:233-7.

32. Suter VG, Altermatt HJ, Sendi P, Mettraux G, Bornstein MM. CO2 and diode laser for excisional biopsies of oral mucosal lesions. A pilot study evaluating clinical and histopathological parameters. Schweizer Monatsschrift fur Zahnmedizin = Revue mensuelle suisse d'odontostomatologie $=$ Rivista mensile svizzera di odontologia e stomatologia/SSO 2010;120:664-71.

33. Boj JR, Poirier C, Hernandez M, Espassa E, Espanya A. Case series: laser treatments for soft tissue problems in children. European archives of paediatric dentistry : official journal of the European Academy of Paediatric Dentistry 2011; 12:113-7.
34. Boj JR, Poirier C, Hernandez M, Espassa E, Espanya A. Review: laser soft tissue treatments for paediatric dental patients. European archives of paediatric dentistry : official journal of the European Academy of Paediatric Dentistry 2011;12:100-5.

35. Kumar R, Jain G, Dhodapkar SV, Kumathalli KI, Jaiswal G. The Comparative Evaluation of Patient's Satisfaction and Comfort Level by Diode Laser and Scalpel in the Management of Mucogingival Anomalies. Journal Of Clinical And Diagnostic Research : JCDR 2015;9:ZC56-8.

36. Farista S, Kalakonda B, Koppolu P, Baroudi K, Elkhatat E, Dhaifullah E. Comparing Laser and Scalpel for Soft Tissue Crown Lengthening: A Clinical Study. Global Journal Of Health Science 2016;8:55795.

37. El Shenawy HM, Nasry SA, Zaky AA, Quriba MA. Treatment of Gingival Hyperpigmentation by Diode Laser for Esthetical Purposes. Open access Macedonian Journal Of Medical Sciences 2015;3:447-54.

38. Reddy Kundoor VK, Patimeedi A, Roohi S, Maloth KN, Kesidi S, Masabattula GK. Efficacy of Diode Laser for the Management of Potentially Malignant Disorders. Journal Of Lasers İn Medical Sciences 2015;6:120-3.

39. Ize-Iyamu IN, Saheeb BD, Edetanlen BE. Comparing the $810 \mathrm{~nm}$ diode laser with conventional surgery in orthodontic soft tissue procedures. Ghana Medical J 2013;47:107-11.

40. Gontijo I, Navarro RS, Haypek P, Ciamponi AL, Haddad AE. The applications of diode and Er:YAG lasers in labial frenectomy in infant patients. J Dent Child (Chic) 2005;72:10-5.

41. Pick RM, Colvard MD. Current status of lasers in soft tissue dental surgery. Journal Of Periodontology 1993;64:589-602.

\section{Yazışma Adresi}

Hatice BALCI YUCE, Ph.D.

Department of Periodontology

Gaziosmanpaşa University Faculty of Dentistry

Tokat 60100, Turkey

Tel: +903562124222

Fax: +903562124225

E-mail: htbalci@gmail.com 